\section{'Metolius' Trailing Blackberry}

\section{Chad E. Finn}

U.S. Department of Agriculture, Agricultural Research Service, Horticultural Crops Research Laboratory, Northwest Center for Small Fruit Research, Corvallis, OR 97330

\section{Brian M. Yorgey}

Department of Food Science, Oregon State University, Corvallis, OR 97331

Bernadine C. Strik

Department of Horticulture, Oregon State University, Corvallis, OR 97331

\section{Robert R. Martin}

U.S. Department of Agriculture, Agricultural Research Service, Horticultural Crops Research Laboratory, Northwest Center for Small Fruit Research, Corvallis, OR 97330

Additional index words. Rubus, fruit breeding, fresh market, early ripening

'Marion' is currently the most important blackberry (Rubus L. subgenus Rubus) cultivar in the world but it is primarily grown for the processing market (Finn et al., 1997). 'Chester Thornless' has been the most important fresh market cultivar in recent years (Clark, 1992; Strik, 1992). The recent expansion of the blackberry fresh market has led to significantly increased plantings of a number of new erect and trailing blackberry cultivars from private and public programs (J. Clark and R. Harrison, personal communication). While 'Chester Thornless' has admirable traits, particularly high yields of firm fruit, there is a need for cultivars that have better eating quality, can be shipped between hemispheres, and are adapted to atypical blackberry environments, e.g., low chilling. The older trailing blackberry cultivars such as the 1950 release 'Olallie' (Waldo, 1950), have soft fruit, and though they were shipped widely on the wholesale fresh market as recently as 2001, are falling out of favor despite their outstanding flavor. In addition to excellent fruit quality, the trailing blackberries have an advantage in cool springtime climates as are found along the West Coast and in the Willamette Valley, Ore., where the fruit ripen significantly earlier than either the erect or semi-erect cultivars. 'Metolius' and 'Obsidian' (Finn et al., 2005b) have been released simultaneously as new early ripening, trailing blackberry cultivars for the fresh market that combine earliness and excellent fruit quality with excellent horticultural traits.

'Metolius' is a new trailing blackberry from the U.S.Department of Agriculture-Agricultural Research Service (USDA-ARS) breeding program in Corvallis, Ore., released in cooperation with the Oregon State University Agricultural

Received for publication 8 June 2005. Accepted for publication 18 Aug. 2005. This research was partially funded by the Oregon Raspberry and Blackberry Commission and the Northwest Center for Small Fruit Research. We gratefully acknowledge the assistance of Mary Peterson, Connie Pace, and Gloria Murray in 'Metolius's evaluation; Nola Mosier for producing nuclear stock free of known viruses; Mark Hurst of Hurst's Berry Farm (Sheridan, Ore.) for storage trials; and Derek Peacock, formerly of Enfield Farms (Lynden, Wash.), for trial results.
Experiment Station and the Washington State UniversityAgricultural Research Center. 'Metolius' is very early ripening, with medium-sized, firm, uniform shaped fruit and very good yields of excellent quality fresh fruit.

\section{Origin}

In 1997, 'Metolius', tested as ORUS 1452-1, was selected from a 1994 cross between 'Douglass' and 'Kotata' (Fig. 1). 'Douglass' (USPP 8423; Douglass, 1993) is an early thornless trailing blackberry with soft fruit but excellent flavor. While 'Douglass' was developed by a private breeder, several of its progenitors were originally from the USDA-ARS program in
Corvallis. Although, 'Douglass' parents were published in the patent, the full pedigree has not been published previously. 'Kotata' is an early to midseason commercial trailing cultivar that is very thorny, has good yield and has excellent fruit quality. While 'Kotata' fruit must be handled gently, it can be shipped in the wholesale fresh market. The ploidy level of 'Metolius' is unknown and is difficult to estimate. The maternal parent 'Kotata' is heptaploid $(2 \mathrm{n}=7 \mathrm{x}=49)$ and paternal 'Douglass' is octoploid $(2 \mathrm{n}=8 \mathrm{x}=$ 56) (Meng and Finn, 2002; Thompson, 1995). 'Metolius' is being released primarily due to its superior performance as a very early ripening fresh market berry. The cultivar is named after a famous Oregon trout fishing river that emerges from a large spring at the base of Black Butte, in the central Oregon Cascade Mountains.

\section{Description and Performance}

While 'Metolius' has been tested on a commercial grower site in northern Washington and at research sites in Oregon, the most thorough testing was done at the Oregon State University North WillametteResearch and Extension Center (NWREC) in Aurora, Ore. In each planting, standard cultural practices for trailing blackberry production were used, including annual pre- and postemergent herbicide applications, spring nitrogen fertilization ( $78 \mathrm{~kg} \mathrm{~N} / \mathrm{ha})$, postharvest removal of floricanes, training of primocanes to a two wire trellis, and weekly overhead application of about $2.5 \mathrm{~cm}$ of irrigation. The plantings received applications of dormant season fungicides (liquid lime sulfur and copper hydroxide) to control leaf and cane spot (Septoria rubi Westend.), purple blotch [Septocyta ruborum (Lib.) Petr.], rust [Kuehneola uredinis (Link)Arth.] and

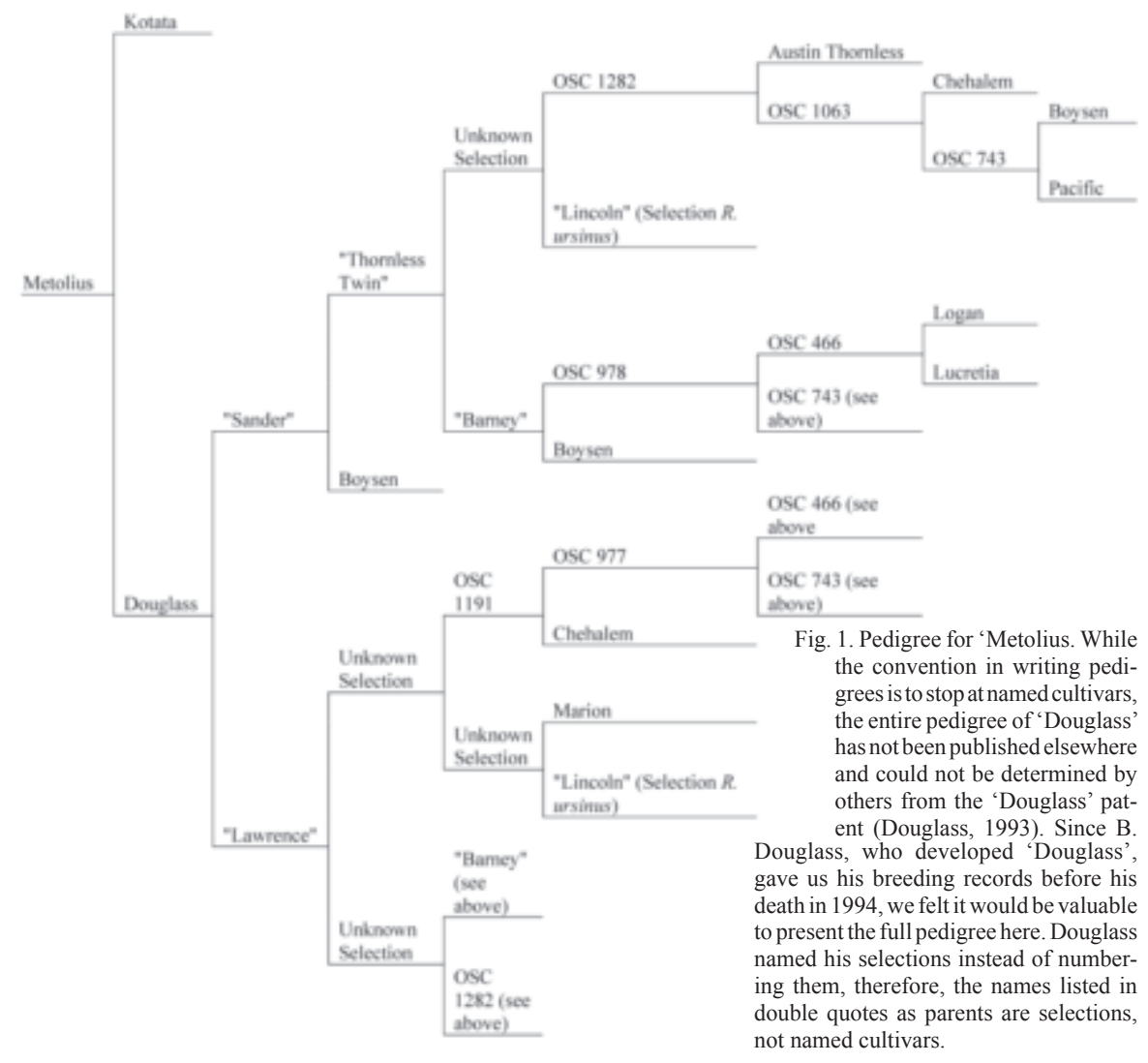


anthracnose [Elsinoe veneta (Burkholder) Jenk.]. They also received a single bloom application of captan to control anthracnose, botrytis (Botrytis cinerea Pers.:Fr.), cane spot, purple blotch and stamen blight [Hapalosphaeria deformans (Syd.) Syd.] at labeled rates. In 1999, 'Metolius' was plantedalong with standard commercial cultivars in a randomized complete block design with four, three-plantreplications used for fresh fruit characteristicsatNWREC. Threereplications werehand harvested once per week to determine, harvest season, yield and fruit weight. The average fruit weight for a season is a weighted mean based on the weight of a randomly selected subsample of 25 fruit from each harvest. These data, collected from 2001-03, were analyzed as a split-plot in time with cultivar as the main plot and year as the subplot. Of the 23 genotypes harvested only the data from 'Marion', 'Silvan', 'Siskiyou', and 'Waldo' and thenew releases 'Metolius', 'Obsidian' (Finn et al., 2005b) and 'Black Diamond' (Finn et al, 2005a) were included in the analysis (PROC GLM, SAS Institute, Cary, N.C.). The cultivar $\times$ year interaction was significant for yield but not for fruit weight. Therefore, the interaction means for yield are presented and compared using Duncan's multiple range test (Table 1). The fruit ripening season in Oregon was characterized by the dates at which $5 \%, 50 \%$, and $95 \%$ of the total fruit yield were harvested.

Table 1. Fruit weight and yield in 2001-03 for blackberry genotypes planted in 1999 in replicated trial at Oregon State University-North Willamette Research and Extension Center in Aurora.

\begin{tabular}{lccccc}
\hline & \multicolumn{2}{c}{$\begin{array}{c}\text { Fruit } \\
\text { size }(\mathrm{g})^{\mathrm{z}}\end{array}$} & & \multicolumn{4}{c}{ Yield $\left(\mathrm{kg} \cdot \mathrm{ha}^{-1}\right)$} \\
\cline { 2 - 6 } & $2001-03$ & 2001 & 2002 & 2003 & $2001-03$ \\
\hline Genotype & $6.8 \mathrm{a}$ & $40895 \mathrm{a}$ & $20148 \mathrm{a}$ & $24087 \mathrm{a}$ & $28377 \mathrm{a}$ \\
Obsidian & $6.2 \mathrm{~b}$ & $31757 \mathrm{ab}$ & $16811 \mathrm{ab}$ & $21485 \mathrm{ab}$ & $23351 \mathrm{~b}$ \\
Silvan & $5.8 \mathrm{bc}$ & $29281 \mathrm{ab}$ & $15568 \mathrm{ab}$ & $19001 \mathrm{a}-\mathrm{c}$ & $21283 \mathrm{bc}$ \\
Black Diamond & $5.1 \mathrm{~d}$ & $26380 \mathrm{ab}$ & $13021 \mathrm{ab}$ & $18397 \mathrm{a}-\mathrm{c}$ & $19266 \mathrm{bc}$ \\
Marion & $5.6 \mathrm{c}$ & $31324 \mathrm{ab}$ & $12547 \mathrm{~b}$ & $12517 \mathrm{c}$ & $18796 \mathrm{bc}$ \\
Metolius & $5.5 \mathrm{c}$ & $25849 \mathrm{ab}$ & $11000 \mathrm{~b}$ & $17286 \mathrm{c}$ & $18045 \mathrm{bc}$ \\
Waldo & $6.9 \mathrm{a}$ & $20969 \mathrm{~b}$ & $9854 \mathrm{~b}$ & $9359 \mathrm{~d}$ & $13394 \mathrm{c}$ \\
Siskiyou & & &
\end{tabular}

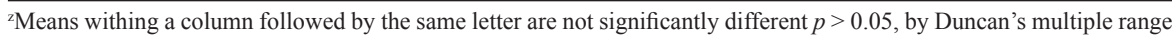
test.

Table 2. Mean ripening season and date at which yield of each blackberry genotype reached the given percentage of total yield and for similar aged 'Willamette' red raspberry plants harvested in the same years in an adjacent planting. at the Oregon State University-North Willamette Research and Extension Center in Auroa. Trial planted in 1999 and harvested in 2001-03.

\begin{tabular}{lccc}
\hline & \multicolumn{3}{c}{ Harvest season } \\
\cline { 2 - 4 } Genotype & $5 \%$ & $50 \%$ & $95 \%$ \\
\hline Metolius & 25 June & 3 July & 14 July \\
Obsidian & 25 June & 4 July & July \\
Silvan & 26 June & 8 July & 21 July \\
Black Diamond & 28 June & 8 Jul & 21 Jul \\
Siskiyou & 25 June & 10 July & 25 July \\
Marion & 3 July & 22 July & 22 July \\
Waldo & 8 July & 7 July & 7 Aug. \\
Willamette red raspberry & 27 June & 21 July \\
\hline
\end{tabular}

Table 3. Yield and harvest season for blackberry genotypes planted in one or two five-plant plots (1.4 m plant spacing) in 2001 and 2002 at Enfield Farms in Lynden, Wash. Plants were harvested primarily with an over-the-row harvester (Littau, Stayton, Ore) with a horizontal (Christy) head.

\begin{tabular}{|c|c|c|c|c|c|}
\hline \multirow[b]{2}{*}{ Genotype } & \multirow{2}{*}{$\begin{array}{c}\text { Yield } \\
\left(\mathrm{kg} \cdot \mathrm{ha}^{-1}\right)\end{array}$} & \multicolumn{3}{|c|}{2003 Harvest season } & \multirow{2}{*}{$\begin{array}{l}\text { No. } \\
\text { plots }\end{array}$} \\
\hline & & $5 \%$ & $50 \%$ & $95 \%$ & \\
\hline Black Diamond & 17281 & 11 July & 21 July & 6 Aug & 2 \\
\hline Nightfall & 14384 & 11 July & 25 July & 6 Aug. & 1 \\
\hline Silvan & 12106 & 11 July & 21 July & 3 Aug. & 2 \\
\hline Marion & 10382 & 11 July & 21 July & 6 Aug. & 2 \\
\hline Siskiyou & 9656 & 11 July & 21 July & 31 July & 1 \\
\hline Boysen & 8670 & 16 July & 25 July & 31 July & 1 \\
\hline Metolius & 8480 & 11 July & 11 July & 25 July & 1 \\
\hline Waldo & 7112 & 21 July & 31 July & 6 Aug. & 2 \\
\hline
\end{tabular}

(Table2). In 2001, 'Metolius'and othergenotypes were planted in plots at Enfield Farms (Lynden, Wash.) along the Canada-U.S. border to assess cold hardiness and suitability formachine harvest. While observations were made on these plants from 2002-04, the winters were relatively mild (minimum winter temperature in winter 2001-02 was $-8.0^{\circ} \mathrm{C}$ with -3.8 and $-9.7^{\circ} \mathrm{C}$ minimums in the following two winters). In 2003, fruit were harvested by an over-the-row (Littau, Stayton, Ore.) harvester with a horizontal (Christy) head from five-plant plots (Table 3). Subjective fruit evaluations were made during the fruiting season using 1 to 9 scale $(9=$ the best expression of each trait). These subjective evaluations were done on cultivars in the replicated trial as well as important commercial cultivars ('Chester Thornless' and 'Kotata') that werenot. The fruitratings included firmness (as measured subjectively by hand in the field on six to eight berries), color, shape (with a uniform, long conic ideal), texture (as measured subjectively when chewed while tasting berries in the field), separation (subjective rating of how easily ripe fruit separated from the plant), and flavor (subjectively rated by tasting berries in the field)(Table4). Plant ratings were conducted one time each year from 2001-03 during the fruiting season for primocane and floricane vigor, spines ( $9=$ spineless), and flowering or fruiting lateral length $(1=$ very short; $5=$ very long $)$ and strength (1 = weak, droopy; 5 = stiff, sturdy) (Table 4). In a separate study, the anthocyanins, phenolics and antioxidant capacity for fruit of a number of blackberry genotypes including 'Metolius' were evaluated (Moyer et al., 2002).

In Oregon, 'Metolius' has had yields comparable to the industry standard 'Marion' and the new release 'Black Diamond' (Table 1). While not always statistically different, 'Metolius' generally had higher yields than 'Siskiyou', which is the current early season standard for the fresh market (Finn et al., 1999), and lower yields than 'Obsidian', which is being released simultaneously and has a similar market to that of 'Metolius'. In northern Washington, yield of 'Metolius' appeared comparable to that of 'Marion', 'Siskiyou', 'Boysen', and 'Waldo' (Table 3). 'Metolius' fruit are medium in size, larger than those of 'Marion' but smaller than 'Siskiyou' or 'Obsidian' (Table 1). While not illustrated in these data, 'Metolius' fruit are very uniform in size (Fig. 2).

'Obsidian' and 'Metolius' are the earliest ripening blackberry cultivars in the Pacific Northwest, ripening their main crop 2-4 weeks earlier than all semi-erect and erect blackberry cultivars and slightly earlier than early-season

Table 4. Mean scores for subjectively evaluated characteristics ${ }^{2}$ of blackberry genotypes planted in the 1990s at the Oregon State University-North Willamette Research and Extension Center in Aurora.

\begin{tabular}{|c|c|c|c|c|c|c|c|c|c|c|c|}
\hline \multirow[b]{2}{*}{ Cultivar } & \multirow{2}{*}{$\begin{array}{c}\text { Primocane } \\
\text { vigor }\end{array}$} & \multirow[b]{2}{*}{ Thorns } & \multirow{2}{*}{$\begin{array}{c}\text { Floricane } \\
\text { vigor }\end{array}$} & \multicolumn{2}{|c|}{ Fruiting lateral } & \multicolumn{6}{|c|}{ Fruit } \\
\hline & & & & Length & Strength & Firm & Color & Shape & Texture & Separation & Flavor \\
\hline Black Diamond & 8.3 & 8.6 & 8.4 & 3.0 & 3.7 & 7.3 & 8.3 & 8.9 & 8.2 & 8.5 & 6.8 \\
\hline Chester Thornless & 9.0 & 9.0 & 8.7 & 4.8 & 3.4 & 7.2 & 8.7 & 6.2 & 5.5 & 8.4 & 6.2 \\
\hline Kotata & 9.0 & 3.3 & 8.6 & 3.2 & 3.9 & 7.4 & 8.9 & 7.7 & 8.4 & 8.8 & 7.7 \\
\hline Marion & 9.0 & 4.6 & 8.5 & 4.8 & 3.3 & 5.4 & 8.3 & 6.7 & 8.9 & 8.9 & 8.6 \\
\hline Metolius & 9.0 & 2.5 & 7.9 & 4.3 & 4.7 & 8.2 & 8.7 & 8.8 & 8.8 & 8.8 & 7.8 \\
\hline Obsidian & 8.9 & 4.9 & 8.8 & 3.5 & 3.3 & 7.7 & 8.6 & 7.5 & 8.0 & 8.2 & 7.5 \\
\hline Siskiyou & 9.0 & 4.0 & 8.5 & 4.1 & 3.6 & 8.1 & 8.7 & 8.1 & 8.5 & 8.9 & 8.2 \\
\hline
\end{tabular}

${ }^{\mathrm{z}}$ Characteristics (except for laterals) scored on a 1 to 9 scale, where $1=$ the poorest expression of the trait and $9=$ the best expression of the trait, i.e., $9=$ very vigorous, spineless, very firm, black, uniform shape, pleasant to chew not seedy, separates easily from the plant, and intense flavor, respectively. Lateral characteristics scored on a 1 to 5 scale, where $1=$ short or weak laterals and $5=$ long or strong laterals. 


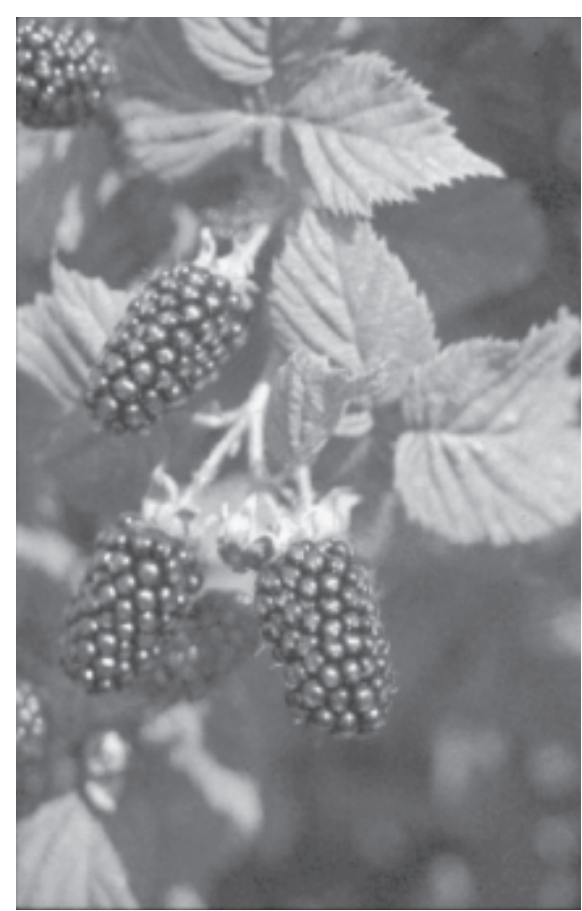

Fig. 2. 'Metolius' fruit.

raspberries suchas 'Willamette'(Table2). 'Metolius' harvest begins in late June, peaks in early July and is largely done by mid-July in Oregon. 'Obsidian' and 'Metolius' have nearly identical harvest seasons that begin about the same time as 'Silvan' or 'Siskiyou' and a little over 1 week earlier than 'Marion'. Both harvest seasons peak 4 to 5 d ahead of 'Silvan', 'Siskiyou', and 'Black Diamond', a week ahead of 'Marion' and 2.5 weeks ahead of 'Waldo'. While the nature of the trials in Washington donotallow precise comparisons, 'Metolius' appears to be much earlier than the other cultivars in that trial (Table 3 ).

Fruit of 'Metolius' are conical in shape with a drupelet arrangement that produces a very uniformly shaped fruit, reminiscent of its 'Kotata' parent (Table 4, Fig. 2). 'Metolius', like 'Black Diamond', has a more uniform shape than 'Marion', 'Chester Thornless', or 'Obsidian'. 'Metolius' fruit have outstanding firmness similar to 'Siskiyou' and firmer than 'Marion'(Table 4). 'Metolius' is very glossy with excellent black color (Table 4). The fruit separate easily from the plant when hand-picked (Table 4) and at Enfield Farms (Lynden, Wash.) when 'Metolius' was harvested by machine, it was noted for being easy to remove and for having a very uniform appearing picked product. When the fruit are eaten, the texture is comparable to the other trailing cultivars, with much less noticeable seeds than 'Chester Thornless' and slightly less noticeable seeds than 'Obsidian'. The 'Metolius' flavor is not as aromatic as 'Marion' but is more pleasant than 'Chester Thornless'. Fruit firmness and flavor were evaluated at full-ripe because fruit for processing are harvested at that stage. However, for fresh market, most fruit are harvested at a full black, not a full-ripe stage. 'Metolius' fruit harvested at the full-black stage have excellent firmness and very good flavor described as pleasant and sweet. While 'Metolius' appears to make a nice fresh pack and ship well, if stored refrigerated for long periods ( $22 \mathrm{~d}$ ) it will get soft, leaky, and moldy.

In 2000, Moyer et al. (2002) hand-harvested fruit at peak ripeness, immediately cooled them, and transported them to the Oregon State University Department of Food Science and Technology for analysis of total phenolics, total anthocyanins, oxygen radical absorbance capacity (ORAC), and ferric reducing antioxidant power (FRAP). 'Metolius' had lower anthocyanin levels than did 'Marion', 'Obsidian', and 'Chester Thornless' but had slightly higher ones than those of 'Black Diamond'. 'Metolius' had total phenolic levels comparable to 'Obsidian', much higherthan 'Chester Thornless and 'Black Diamond', but lower than those of 'Marion' and 'Siskiyou'. While the ORAC and FRAP levels were lower than those for 'Marion', they were higher than those of 'Obsidian' and 'Black Diamond' and slightly higher than those for 'Chester Thornless'. While 'Metolius' ORAC values were greater than those for 'Siskiyou', its FRAP values were much less.

'Metolius' plants are not as large as those of 'Marion' or 'Obsidian' but are comparable to those of 'Black Diamond' (Table 4). While noted previously for its suitability for machine harvest, 'Metolius' would not be recommended for machine harvesting for a processed product because of its thorniness (Strik and Buller, 2002). 'Metolius' has flowering laterals that are medium-long in length and stiff (Table 4). The lateral stiffness means the fruit are well presented for hand harvest but they sometimes break when harvested by machine.

In our trials, under a minimal spray program, 'Metolius' has been free of serious cane, leaf, or fruit diseases. 'Metolius' is not particularly susceptible to Septoria leaf spot and purple blotch. 'Metolius' has not exhibited vegetative or fruit symptoms of cane and leaf rust. In some years, particularly 1997, 'Marion', 'Kotata', and 'Black Butte' were severely damaged by a dryberry syndrome. The cause of this problem is not known currently but is suspected to be a complex of diseases, particularly anthracnose, that develops under certain combinations of temperature and moisture. 'Metolius' has shown no symptoms of dryberry in our trials.

No significant winter injury has been noted on the genotype since it was selected in 1997, however, the Pacifc Northwestern U.S. winters, even in northern Washington, have been relatively mild. No winter injury has ever been noted on 'Metolius' in Oregon, even after precipitous temperature drops the last few days of October 2002 and 2003 (temperatures dropped rapidly to -3 to $-6^{\circ} \mathrm{C}$ ) when some cultivars, including 'Marion' had cold injury. In October 2003 , similar rapid temperature drops (to -4 to $-8^{\circ} \mathrm{C}$ ) occurred in Lynden, Wash. and while 'Marion' had significant bud and cane damage in Spring 2004, 'Metolius' appeared to be uninjured.

Outstanding characteristics of 'Metolius' include early ripening crops of medium and uniformly sized, uniformly shaped, glossy, firm fruit with excellent color and flavor, moderate yields, and vigorous plants. 'Metolius' should perform well as a fresh market cultivar. In comparison with 'Obsidian', which is being released for similar early season fresh market uses, 'Metolius' seems to have superiorfirmness, which is critical for shipping, and greater fruit uniformity, whereas 'Obsidian' is much higher yielding and has larger fruit with good firmness. A comparative photograph is published in Finn et al. (2005b). While 'Metolius' also produces an excellent processed product, its thorns may prevent it from being popular for that market. 'Metolius' is expected to perform well in areas where trailing blackberries are adapted including the Pacific Northwest, California, Chile, New Zealand, United Kingdom, and the Mediterranean region.

\section{Availability}

'Metolius' is not patented. When this germplasm contributes to the development of a new cultivar or germplasm, the authors request that appropriate recognition be given to the source. 'Metolius' nuclear stock has tested negative for tomato ringspot, raspberry bushy dwarf, and tobacco streak viruses by ELISA and has indexed negative on grafting to $R$. occidentalis. Further information or a list of nurseries propagating 'Metolius' is available on written request to the contact author. The USDA-ARS does not have commercial quantities of plants to distribute. In addition, plants of 'Metolius' have been deposited in the National Plant Germplasm System, USDA-ARS National Clonal Germplasm Repository at Corvallis. accession number PI 638262, where it is available for research purposes, including development and commercialization of new cultivars.

\section{Literature Cited}

Clark, J.R. 1992. Blackberry production and cultivars in North America east of the Rocky Mountains. Fruit Var. J. 46:217-222.

Douglass, B. S. 1993. Blackberry-Douglass cultivar. United States Patent 8,423. U.S. Patent and Trademark Office, Wash., D.C.

Finn, C.E., F.J. Lawrence, B.C. Strik, B. Yorgey, and J. DeFrancesco. 1999. 'Siskiyou' trailing blackberry. HortScience 34:1288-1290.

Finn, C., B.C. Strik, and F.J. Lawrence. 1997. Marion trailing blackberry. Fruit Var. J. 51:130-132.

Finn, C.E., B.M. Yorgey, B.C. Strik, H.K. Hall, R.R. Martin, and M.C. Qian. 2005a. 'Black Diamond'thornless trailing blackberry. HortScience 2175-2178.

Finn, C.E., B.M. Yorgey, B.C. Strik, R.R. Martin, and C. Kempler. 2005b. 'Obsidian' trailing blackberry. HortScience 40:2185-2188.

Meng, R. and C. Finn. 2002. Determining ploidy level and nuclear DNA content in Rubus by flow cytometry. J. Amer. Soc. Hort. Sci. 127:767-775.

Moyer, R.A., K.E. Hummer, C.E. Finn, B. Frei, and R.E. Wrolstad. 2002.Anthocyanins, phenolics and antioxidant capacity in diverse small fruits: Vaccinium, Rubus, and Ribes. J. Agr. Food Chem. 50:519-525.

Strik, B.C. 1992. Blackberry cultivars and production trends in the Pacific Northwest. Fruit Var. J. 46:202-206.

Strik, B. and G. Buller. 2002. Reducing thorn contamination in machine-harvested 'Marion' blackberry. Acta Hort. 585:677-681

Thompson, M.M. 1995. Chromosome numbers of Rubus cultivars at the National Clonal Germplasm Repository. HortScience 30:1453-1456.

Waldo, G.F. 1950. Notice of naming and release of a new blackberry adapted to the Pacific Coast region. USDA Release Notice. 